\title{
Early feeding to modify digestive enzyme activity in broiler chickens
}

\section{La alimentación temprana como modificador de la actividad de enzimas digestivas en pollos de engorde}

\author{
Milagro León T, M.Sc, Gerardo Garrido G, M.Sc, María Castañeda D, TSU, \\ Emma Rueda de A, Ph.D.
}

Central University of Venezuela, Faculty of Veterinary Science, Department of Biomedical Science, Nutritional Biochemistry Center, Enzymology and Toxicology Laboratory. Final Prolongation 19 de Abril Avenue, El Limón Lane, Maracay, Venezuela. Correspondence: emmarueda@gmail.com.

Received: November 2013; Accepted: March 2014.

\begin{abstract}
Objective. To evaluate the effect on digestive enzyme activity in broiler chickens by providing food in the first $48 \mathrm{hrs}$. after birth. Materials and methods. After incubating 300 fertile eggs from Hubbard breeding and immediately after hatching, the chicks were randomly assigned to treatments: fasting (from hatching to 48 hrs.); Hydrated Balanced Food (HBF) from birth to 48 hrs.; commercial hydrating supplement (CHS) from birth to $48 \mathrm{hrs}$. The diets were provided ad libitum. After $48 \mathrm{hrs}$. a commercial diet was fed. At birth and at 48 and 72 hrs. of age 30 chicks/treatment were sacrificed to determine the enzyme activity of maltase, sucrase, alkaline phosphatase, phytase, $\alpha$-amylase, trypsin and lipase in samples of duodenal or pancreatic homogenate. Results. The supply of HBF or CHS during the first 48 hrs. of life increased the activity of maltase, sucrase and phytase in the first 3 days of life, with values between 1.2 and up to 4 -fold compared to the control $(p<0.05)$. Chickens that fasted for the first 48 hrs. had higher activity of the pancreatic enzymes $\alpha$-amylase, trypsin, and lipase at 72 hrs. of life $(p<0.05)$. Conclusions. The food supply in the first $48 \mathrm{hrs}$. after hatching increases the duodenal enzyme activity in the intestinal brush border during the first 3 days of age in broiler chickens.
\end{abstract}

Key words: Feeding, diet, enzymes, broiler chickens (Source: Agrovoc).

\section{RESUMEN}

Objetivo. Evaluar el efecto sobre la actividad de enzimas digestivas en pollos de engorde al suministrar alimento en las primeras $48 \mathrm{~h}$ de nacidos. Materiales y métodos. Después de incubar 300 huevos fértiles provenientes de reproductoras Hubbard e inmediatamente después de la eclosión, los pollos fueron asignados al azar a los tratamientos: ayuno (desde la eclosión hasta $48 \mathrm{~h}$ ); alimento balanceado hidratado $(\mathrm{ABH})$ desde el nacimiento hasta las $48 \mathrm{~h}$; suplemento hidratante comercial (SHC) desde el nacimiento hasta las $48 \mathrm{~h}$. Las dietas fueron suministradas ad libitum. A partir de las $48 \mathrm{~h}$ se suministró una dieta comercial. Al nacer y a las 48 y $72 \mathrm{~h}$ de nacidos, fueron sacrificados 30 pollos/tratamiento para las determinaciones de las actividades de las enzimas maltasa, sacarasa, fosfatasa alcalina, fitasa, $\alpha$-amilasa, tripsina y lipasa en muestras de homogenado duodenal o pancreático. Resultados. El suministro de $\mathrm{ABH}$ o SHC durante las primeras $48 \mathrm{~h}$ de vida aumentó la actividad de 
maltasa, sacarasa y fitasa en los primeros 3 días de edad, con valores entre 1.2 y hasta 4 veces en comparación con el control $(p<0.05)$. Los pollos en ayuno durante las primeras $48 \mathrm{~h}$ presentaron mayor actividad de las enzimas pancreáticas $\alpha$-amilasa, tripsina y lipasa a las $72 \mathrm{~h}$ de vida $(p<0.05)$. Conclusiones. El suministro de alimentos en las primeras $48 \mathrm{~h}$ después de la eclosión aumenta la actividad de las enzimas duodenales del borde en cepillo intestinal durante los primeros 3 días de edad en pollos de engorde.

Palabras clave: Alimentación, dieta, enzimas, pollo de engorde (Fuente: Agrovoc).

\section{INTRODUCTION}

In current poultry production, physical separation between the hatchery and farms can cause newborn chickens to spend a variable period of time without food, and usually between 36 to $48 \mathrm{hrs}$. pass after birth before birds have access to feed, reducing the weight of the birds during this time (1). Delayed feed consumption can reduce the rate of growth and cause weight loss (2).

By contrast, immediate access to food and water after hatching may promote development of the digestive tract, increase body weight (3.4) and reduce mortality in the first 3 days of life (5).

With early feeding, nutrients necessary for infants are supplied during the first 48-72 hrs. It has been reported that this can reduce dehydration and promote rapid reabsorption of the yolk sac (6), the development of the liver, pancreas and intestine (7), increase the bird's immediate development post-hatch, improve young chickens' resistance against exposure to low temperatures (8) and promote further development of the immune system (9).

When studying the effect of feeding immediately after hatching on activation of the genetic program that regulates hepatic lipogenesis, it was found that during the first week after hatch regulating key lipogenic genes was significant, including ATP citrate lyase enzymes, malic enzyme, fatty acid synthase, acetyl-CoAcarboxilasa, alpha stearyl-CoA desaturase-1, etc. (10). Food restriction during the first $48 \mathrm{hrs}$. post-hatching caused a significant decrease in weight gain, plasma glucose and the regulation of lipogenic genes, which reverts to the beginning of feeding (10). There are no previous reports about how digestive enzyme activity can be affected, mainly those that are an integral part of the intestinal brush border, such as disaccharidases, phosphatases and phytase.

It is of practical interest to study nutritional requirements and effects of early feeding in birds at an early age, or in the period of time

\section{INTRODUCCIÓN}

En la producción avícola actual, la separación física entre la planta incubadora y las granjas puede ocasionar que los pollos recién nacidos pasen un período variable de tiempo sin agua ni alimento $y$, generalmente, transcurren entre 36 y $48 \mathrm{~h}$ después del nacimiento para que las aves tengan acceso al alimento, reduciéndose en este período el peso de las aves (1). Un retraso en el consumo de alimento puede reducir la tasa de crecimiento y provocar pérdidas de peso (2).

Por el contrario, el acceso inmediato al alimento y al agua después de la eclosión puede promover el desarrollo del tracto digestivo, aumentar el peso corporal $(3,4)$ y disminuir la mortalidad en los primeros 3 días de edad (5).

Con la alimentación temprana se suministran nutrientes necesarios para los pollos recién nacidos durante las primeras 48 a $72 \mathrm{~h}$. Se ha reportado que esta práctica puede reducir la deshidratación y promover la rápida reabsorción del saco vitelino (6), el desarrollo del hígado, páncreas e intestino (7), incrementar el desarrollo del ave inmediatamente después de la eclosión, mejorar la resistencia contra la exposición a las bajas temperaturas en pollos jóvenes (8) y promover un mayor desarrollo del sistema inmunitario (9).

Al estudiar el efecto de la alimentación, inmediatamente después de la eclosión sobre la activación del programa genético que regula la lipogénesis hepática, se encontró que durante la primera semana post eclosión fue significativa la regulación de los genes clave lipogénicos incluyendo los de las enzimas ATP citrato liasa, enzima málica, ácido graso sintasa, acetil-CoA carboxilasa, alfa estearil-CoA desaturasa-1, entre otros (10). La restricción de alimentos durante las primeras $48 \mathrm{~h}$ post-eclosión provocó una disminución significativa de la ganancia de peso, de la glucosa en plasma y de la regulación de los genes lipogénicos, que se revierte al iniciarse la alimentación (10). No existen reportes previos acerca de cómo puede afectarse la actividad de enzimas digestivas, principalmente las que forman parte integral del borde en cepillo intestinal, tales como las disacaridasas, fosfatasas y fitasa. 
from hatching to their arrival at the farm, on the development of the gastrointestinal tract, as it can affect body development. Therefore, this research was conducted in order to evaluate the effect of providing two different supplements at an early age on the activity of pancreatic and duodenal digestive enzymes in broiler chickens.

\section{MATERIALS AND METHODS}

Incubation and hatching of fertile eggs. A total of 300 fertile eggs from the Hubbard breeder line of hens, 33 weeks old, purchased from the Vipraca Farm, CA located in the state of Yaracuy, were incubated at $37.8^{\circ} \mathrm{C}$ in a Chick master hatchery with automatic dump from the Nutritional Biochemistry Center of the Faculty of Veterinary Science (FVS) at the Central University of Venezuela (CUV) located 67'36'36" east longitude, $10^{\circ} 16^{\prime} 20^{\prime \prime}$ north latitude and 443 meters above sea level, with an average temperature of $25.1^{\circ} \mathrm{C}$ and an average annual rainfall of $1063 \mathrm{~mm}$.

At hatching, the chicks were removed from the hatcher, assigned to metal battery cages for their accommodation in the Department of Biochemistry's animal facility at the FVS-CUV, maintained in suitable conditions of hydration, ventilation and density, and immediately subjected to experimental treatments (100 birds / treatment). The food and water were provided ad libitum from hatching to 72 hours old.

Management of birds and feeding. The hydrated balanced feed was formulated in accordance with international recommendations (11). In Tables 1, 2 and 3, the composition and compositional analysis are shown (12) for the food and food supplements provided. All birds received water ad libitum. In order to take their measurements, at birth and at 48 and 72 hrs. of age, they were sacrificed by cervical dislocation, 30 chicks / treatment / interval to extract, at temperatures between 0 and $4^{\circ} \mathrm{C}$, the duodenal segments and pancreas from which the homogenates were prepared to determine intestinal enzyme activity for maltase, sucrase, alkaline phosphatase and phytase. In duodenal homogenate samples, pancreatic enzyme activity was determined for a-amylase, trypsin and the activity of lipase was determined in samples of pancreatic homogenate. International ethical standards for animal research were respected, avoiding the provocation of pain or suffering.

Experimental design and treatment. Birds were assigned in a completely randomized design
Es de interés práctico el estudio de los requerimientos nutricionales y los efectos de alimentar las aves a temprana edad, o en el intervalo de tiempo que transcurre desde la eclosión hasta su llegada a la granja, sobre el desarrollo del tracto gastrointestinal, ya que puede repercutir en el desarrollo corporal, por lo cual se realizó la presente investigación con el objetivo evaluar el efecto de suministrar dos suplementos diferentes a temprana edad sobre la actividad de enzimas digestivas duodenales y pancreáticas en pollos de engorde.

\section{MATERIALES Y MÉTODOS}

Incubación y eclosión de los huevos fértiles. Un total de 300 huevos fértiles, provenientes de gallinas reproductoras de la línea Hubbard de 33 semanas de edad, adquiridos de la Granja Vipraca, C.A. ubicada en el estado Yaracuy, fueron incubados a $37.8^{\circ} \mathrm{C}$ en una incubadora-nacedora, marca Chick master, con volteo automático del Centro de Bioquímica Nutricional de la Facultad de Ciencias Veterinarias (FCV) de la Universidad Central de Venezuela (UCV) ubicada a 67036'36" longitud este, $10^{\circ} 16^{\prime} 20^{\prime \prime}$ latitud norte y 443 m.s.n.m, con una temperatura media de $25.1^{\circ} \mathrm{C}$ y una pluviosidad promedio anual de $1063 \mathrm{~mm}$.

En la eclosión, los pollos fueron extraídos de la nacedora, asignados a jaulas metálicas de batería para su alojamiento en el bioterio de la Cátedra de Bioquímica de la FCV-UCV, mantenidos en adecuadas condiciones de hidratación, ventilación y densidad, y sometidos de inmediato a los tratamientos experimentales (100 aves/tratamiento). Los alimentos y el agua fueron suministrados ad libitum desde la eclosión hasta las 72 horas de edad.

Manejo de las aves y alimentación. $E L$ alimento balanceado hidratado fue formulado de acuerdo con las recomendaciones internacionales (11). En las tablas 1,2 y 3 se presenta la composición y el análisis bromatológico (12) de los alimentos y suplementos suministrados. Todas las aves recibieron agua a voluntad. Para realizar las respectivas mediciones, al nacer y a las 48 y $72 \mathrm{~h}$ de nacidos, fueron sacrificados, por dislocación cervical, 30 pollos/tratamiento/intervalo, para extraer, a temperaturas entre 0 y $4^{\circ} \mathrm{C}$, los segmentos duodenales y el páncreas a partir de los cuales se prepararon los homogenizados para las determinaciones de las actividades de las enzimas intestinales maltasa, sacarasa, fosfatasa alcalina y fitasa. En las muestras de homogenizado duodenal se determinó la actividad de las enzimas pancreáticas $\alpha$-amilasa, tripsina y la actividad de la lipasa se determinó en muestras de homogenizado pancreático. 
Table 1. Characteristics of hydrated balanced feed

\begin{tabular}{lc}
\multicolumn{1}{c}{ (HBF). } & $\mathbf{g / K g}$ \\
\hline Ingredients & 543 \\
\hline Cornmeal & 350 \\
Soybean meal & 60 \\
Soybean oil & 20 \\
Monocalcium phosphate & 15 \\
Calcium carbonate & 6 \\
Vitamin-mineral pre-mix ${ }^{1}$ & 3 \\
Salt & 2 \\
DL-Methionine & 1 \\
L-Lysine. HCl & $\mathbf{g / K g}$ \\
Composition & 215.5 \\
\hline Crude protein & 80.3 \\
Ether extract & 33.1 \\
Crude fiber & 12.2 \\
Lysine & 10.2 \\
Calcium & 7.8 \\
Phosphorous & 3,100 \\
AME (Kcal/Kg) & \\
\hline
\end{tabular}

${ }^{1}$ Mineral-vitamin Pre-mix Content $(\mathrm{mg} / \mathrm{kg})$ :

80 Iron, Zinc (ZnO) 40, Manganese 60, 0.8 lodine, 8 Copper, 0.2 Selenium, $0.4 \mathrm{mg}$ Cobalt, Vitamin A 4,500 IU, 1,000 IU Cholecalciferol, Vitamin E 25 IU, Menadione 1.5, 0.02 Vitamin B12, 3 Riboflavin , 5 pantothenic acid, 20 Niacin, 0.5 folic acid, 1.5 Thiamine, 0.5 Biotin, 2.5 Pyridoxine.

${ }^{2}$ Calculated values

3Determined according to AOAC (8)

Table 2. Characteristics of the commercial hydrating supplement (CHS).

\begin{tabular}{lc}
\hline Ingredients & $\mathbf{g} / \mathbf{K g}$ \\
\hline Soy flour & 400 \\
Corn flour & 150 \\
Corn Syrup & 180 \\
Citric Acid & 20 \\
Water & 250 \\
Composition ${ }^{1}$ & $\mathbf{g} / \mathbf{K g}$ \\
\hline Crude protein & 212 \\
Ether extract & 6 \\
Crude fiber & 27 \\
\hline${ }^{1}$ Values determined according to AOAC (8).
\end{tabular}

to the following treatments:

T0: Fasting from hatching to 48 hrs.

T1: Hydrated balanced food (HBF) from hatching to 48 hrs. of life.

T3: Commercial Hydrating Supplement (CHS) from hatching to 48 hrs. of life.

Compositional analysis of food. The compositional analyzes were performed in a commercial laboratory, and included the determination of crude protein, crude fat and crude fiber, according to standardized methods (12).

Preparation of intestinal homogenates. Duodenal segments were extracted at temperatures between 0 and $4^{\circ} \mathrm{C}$, cut longitudinally, laid on a glass plate and gently scraped with a glass slide to obtain the mucous that was homogenized at maximum speed for
Table 3. Compositional analysis of food mixtures.

\begin{tabular}{lcc}
\hline \multicolumn{1}{c}{$\begin{array}{c}\text { Composition } \\
(\mathbf{g} / \mathbf{K g})\end{array}$} & HBF ${ }^{2}$ & CHS $^{3}$ \\
\hline Crude Protein & 264 & 212 \\
Ether Extract & 79 & 6 \\
Crude Fiber & 33 & 27 \\
\hline
\end{tabular}

${ }^{1}$ Values determined according to AOAC (8)

${ }^{2} \mathrm{HBF}=$ Hydrated balanced feed

${ }^{3} \mathrm{CHS}=$ Commercial hydrating supplement

Diseño experimental y tratamientos. Las aves fueron asignadas, en un diseño completamente al azar, a los siguientes tratamientos:

T0: Ayuno desde la eclosión hasta $48 \mathrm{~h}$

T1: Alimento balanceado hidratado $(\mathrm{ABH})$ desde la eclosión hasta las 48 h de vida.

T3: Suplemento hidratante comercial (SHC) desde la eclosión hasta las 48 h de vida.

Análisis bromatológico de los alimentos. LOS análisis bromatológicos fueron realizados en un laboratorio comercial, e incluyeron la determinación de proteína cruda, extracto etéreo y fibra cruda, según los métodos estandarizados (12).

Preparación del homogeneizado intestinal. Los segmentos duodenales fueron extraídos a temperaturas entre 0 y $4^{\circ} \mathrm{C}$, cortados longitudinalmente, colocados sobre una placa de vidrio y raspados suavemente con una lámina portaobjeto para obtener la mucosa que fue homogeneizada a máxima velocidad durante $1 \mathrm{~min}$ en solución tampón con 2 mM de HEPES a pH 7.1 y almacenada en alícuotas $\mathrm{a}-20^{\circ} \mathrm{C}$ hasta el momento del análisis, en un lapso no mayor a 15 días.

Preparación del homogenizado pancreático. Todo el procedimiento se realizó entre 0 y $4^{\circ} \mathrm{C}$. Los páncreas fueron homogeneizados, a máxima velocidad, por $3 \mathrm{~min}$ en $4 \mathrm{~g} / \mathrm{ml}$ de solución salina fisiológica, filtrados a través de un liencillo estéril y el extracto almacenado en alícuotas a $-20^{\circ} \mathrm{C}$ hasta que fueron requeridos para las determinaciones enzimáticas, en un lapso de tiempo no mayor a 15 días.

Actividades enzimáticas. Los análisis enzimáticos se realizaron en el Laboratorio de Enzimología y Toxicología adscrito a la Cátedra de Bioquímica, FCV-UCV. Se analizaron réplicas de homogenizado compuestas, en todos los casos, por un pool proveniente de 3 pollos para un total de 10 determinaciones/tratamiento en cada intervalo de tiempo.

Maltasa (EC 3.2.1.20) y Sacarasa (EC 3.2.1.48). La actividad específica de las disacaridasas maltasa y sacarasa fue determinada utilizando como sustrato una solución de maltosa o sacarosa $56 \mathrm{mM}$ en maleato de sodio $100 \mathrm{mM}$ a $\mathrm{pH} 6.0$ y disuelto en $\mathrm{NaOH}$ al 15\% (p/v) (13). La mezcla de reacción 
1 min in buffer with 2 mM HEPES pH 7.1 and stored in aliquots at $-20^{\circ} \mathrm{C}$ until analysis, within a period not exceeding 15 days.

Pancreatic homogenate preparation. The entire procedure was conducted between 0 and $4^{\circ} \mathrm{C}$. The pancreas were homogenized at maximum speed for $3 \mathrm{~min}$ at $4 \mathrm{~g} / \mathrm{ml}$ of physiological saline, filtered through a sterile cotton cloth and the extract was stored in aliquots at $-20^{\circ} \mathrm{C}$ until they were required for enzymatic determinations, within a period no longer than 15 days.

Enzymatic activities. Enzyme analyzes were performed at the Enzymology and Toxicology Laboratory attached to the Department of Biochemistry, FVS-CUV. Homogenized composite replicas were analyzed in all cases, with a pool of 3 chicks for a total of 10 determinations / treatment in each time interval.

Maltase (EC 3.2.1.20) and Sucrase (EC 3.2.1.48). The specific activity of the disaccharidases maltase and sucrase was determined using $56 \mathrm{mM}$ maltose or sucrose as substrate in $100 \mathrm{mM}$ sodium maleate, $\mathrm{pH} 6.0$ and dissolved in $15 \% \mathrm{NaOH}(\mathrm{w} / \mathrm{v})(13)$. The reaction mixture was incubated at $41^{\circ} \mathrm{C}$, for 15 and $30 \mathrm{~min}$ for maltase and sucrase respectively, after which stopped by placing the tubes in boiling water for $20 \mathrm{sec}$. The amount of glucose released in the reaction was quantified using a GOD-PAP kit $900 \AA$ Bioscience. The absorbance was measured in a spectrophotometer (Perkin Elmer, Lambda 11 , California, USA) at a wavelength of $510 \mathrm{~nm}$. The specific activity was expressed as nmoles of glucose released / $\mathrm{min} / \mathrm{mg}$ protein (13).

Alkaline phosphatase (EC 3.1.3.1). The activity of this enzyme was determined using LABTEST ${ }^{\circledR}$ Kits. The alkaline phosphatase present in the sample hydrolyzes the substrate thymolphthalein monophosphate, releasing thymolphthalein and inorganic phosphate. 50 $\mu \mathrm{l}$ of substrate, $500 \mu \mathrm{l}$ of buffer supplied by the manufacturer and $50 \mu \mathrm{l}$ of the sample were incubated for $10 \mathrm{~min}$ at $41^{\circ} \mathrm{C}$. The reaction was stopped with a solution containing 150 $\mathrm{mM}$ sodium carbonate and $100 \mathrm{mM}$ sodium hydroxide. Absorbance was measured in a spectrophotometer at a wavelength of $590 \mathrm{~nm}$ and compared against a known concentration standard. The activity was expressed in (Units/L)/ $\mathrm{min} / \mathrm{mg}$ protein (13).

Phytase (EC 3.1.3.8). Determined at $41^{\circ} \mathrm{C}$ by incubating $40 \mu \mathrm{l}$ of duodenal homogenate with $200 \mu \mathrm{l}$ of $1 \mathrm{mM}$ inositolhexaphosphoric sodium salt and $200 \mu \mathrm{l}$ of $25 \mathrm{mM} \mathrm{MgCl}_{2}$ and $50 \mathrm{mM}$ MES fue incubada, a $41^{\circ} \mathrm{C}$, durante 15 y 30 min para maltasa y sacarasa respectivamente, luego de lo cual se detuvo colocando los tubos en agua en ebullición por $20 \mathrm{seg}$. La cantidad de glucosa liberada en la reacción fue cuantificada utilizando un kit Bioscience GOD-PAP $900^{\circledR}$. La absorbancia se cuantificó en un espectrofotómetro (Perkin Elmer, Lambda 11, California, USA) a una longitud de onda de $510 \mathrm{~nm}$. La actividad específica se expresó como nmoles de glucosa liberada/min/mg de proteína (13).

Fosfatasa alcalina (EC 3.1.3.1). La actividad de esta enzima fue determinada utilizando Kits LABTEST ${ }^{\circledR}$. La fosfatasa alcalina presente en la muestra hidroliza al sustrato timolftaleína monofosfato, liberando timolftaleína y fosfato inorgánico. Se incubaron $50 \mu \mathrm{l}$ de sustrato, $500 \mu \mathrm{l}$ de tampón suministrado por el fabricante y $50 \mu \mathrm{l}$ de la muestra durante $10 \mathrm{~min}$ a $41^{\circ} \mathrm{C}$. La reacción de detuvo con una solución conteniendo carbonato de sodio $150 \mathrm{mM}$ e hidróxido de sodio $100 \mathrm{mM}$. La absorbancia fue medida en el espectrofotómetro a una longitud de onda de $590 \mathrm{~nm}$ y comparada contra la de un patrón de concentración conocida. La actividad se expresó en (Unidades/L)/min/mg de proteína (13).

Fitasa (EC 3.1.3.8). Se determinó a $41^{\circ} \mathrm{C}$ incubando $40 \mu \mathrm{l}$ del homogenado duodenal con 200 $\mu \mathrm{l}$ de la sal sódica de inositol hexafosfórico $1 \mathrm{mM}$ y $200 \mu \mathrm{l}$ del tampón conteniendo $25 \mathrm{mM}$ de $\mathrm{MgCl}_{2}$ y $50 \mathrm{mM}$ de MES a pH 6.0. La reacción se detuvo agregando $3600 \mu \mathrm{l}$ de una solución con $0.28 \%(\mathrm{p} / \mathrm{v})$ de molibdato de amonio, SDS al $1.1 \%(\mathrm{p} / \mathrm{v})$ y ácido ascórbico al $1.1 \%(\mathrm{p} / \mathrm{v})$. La concentración de fosfato liberado fue determinada en el espectrofotómetro a una longitud de onda de $820 \mathrm{~nm}$. Los valores de absorbancia se compararon con los de una curva estándar elaborada a partir de una solución 0.5 $\mathrm{mM}$ de $\mathrm{KH}_{2} \mathrm{PO}_{4}$ y fue expresada como nmoles de $\mathrm{PO}_{4}$ hidrolizados/minuto/mg de proteína $(13,14)$.

$\alpha$-Amilasa (EC 3.2.1.1). El homogenado ( $50 \mu \mathrm{l}$ ) se incubó durante $15 \mathrm{~min}$ a $41^{\circ} \mathrm{C}$ en una mezcla de reacción conteniendo $100 \mu \mathrm{l}$ de Tris- $\mathrm{HCl} 160 \mathrm{mM}$ a pH 7.5 y $200 \mu \mathrm{l}$ de almidón al $0.15 \%$ en ácido sórbico saturado. La reacción se detuvo agregando $100 \mu \mathrm{L}$ de $\mathrm{HCl}$ al $0.5 \mathrm{~N}$ luego de lo cual se añadió 2 $\mathrm{ml}$ de agua destilada y $100 \mu \mathrm{l}$ de solución de yodo $0.01 \mathrm{~N}$. La cantidad de almidón degradado por la amilasa se determinó por espectrofotometría midiendo la disminución de la coloración azul del complejo iónico almidón-yoduro a una longitud de onda de $620 \mathrm{~nm}$ (15). Los valores se compararon con los una curva estándar elaborada a partir de una solución de almidón al $0.15 \%(\mathrm{p} / \mathrm{v})$. La actividad se expresó como $\mu \mathrm{g}$ de almidón degradado/min/ mg de proteína (15). 
buffer $\mathrm{pH}$ 6.0. The reaction was stopped by adding $3600 \mathrm{ml}$ of a solution containing $0.28 \%$ $(\mathrm{w} / \mathrm{v})$ ammonium molybdate, $1.1 \%$ Sodium dodecyl sulfate $(\mathrm{w} / \mathrm{v})$, and $1.1 \%$ ascorbic acid $(w / v)$. The concentration of phosphate released was determined in a spectrophotometer at a wavelength of $820 \mathrm{~nm}$. Absorbance values were compared to a standard curve prepared from a $0.5 \mathrm{mM} \mathrm{KH}_{2} \mathrm{PO}_{4}$ solution and expressed as nmoles of $\mathrm{PO}_{4}$ hydrolyzed/min/mg protein $(13,14)$.

$\alpha$-Amylase (EC 3.2.1.1). The homogenate $(50 \mu \mathrm{l})$ was incubated for $15 \mathrm{~min}$ at $41^{\circ} \mathrm{C}$ in a reaction mixture containing $100 \mu \mathrm{l}$ of $160 \mathrm{mM}$ Tris- $\mathrm{HCl} \mathrm{pH} 7.5$ and $200 \mu \mathrm{l}$ of $0.15 \%$ starch in saturated sorbic acid. The reaction was stopped by adding $100 \mu \mathrm{L}$ of $0.5 \mathrm{~N} \mathrm{HCl}$ after which $2 \mu \mathrm{l}$ of distilled water was added along with $100 \mu \mathrm{l}$ of $0.01 \mathrm{~N}$ iodine solution. The amount of starch degraded by amylase was determined spectrophotometrically by measuring the decrease of blue color of the starch-iodine complex ion at a wavelength of $620 \mathrm{~nm}$ (15). The values were compared to a standard curve prepared from a $0.15 \%$ starch solution (w/v). The activity was expressed as $\mu \mathrm{g}$ of starch degraded/min/ $\mathrm{mg}$ protein (15).

Trypsin (EC 3.4.21.4). Pancreatic homogenate was incubated for $15 \mathrm{~min}$ at $41^{\circ} \mathrm{C}$ with $200 \mu$ of $1 \%(\mathrm{w} / \mathrm{v})$ casein as substrate in $0.1 \mathrm{M}$ sodium phosphate $\mathrm{pH} 7.4$. The reaction was stopped by adding $1 \mu \mathrm{l}$ of $5 \%(\mathrm{w} / \mathrm{v})$ trichloroacetic acid and the mixture was filtered on 42 Whatman paper. $250 \mu \mathrm{l}$ of the filtrate reacted with $1250 \mu \mathrm{l}$ of $0.2 \mathrm{M}$ $\mathrm{Na}_{2} \mathrm{CO}_{3}$ and $250 \mu \mathrm{l}$ Folin-Ciocalteu reagent diluted $1: 5$ in distilled water (16). After incubation for $20 \mathrm{~min}$ at $41^{\circ} \mathrm{C}$ absorbance was measured at a wavelength of $625 \mathrm{~nm}$. The activity was expressed as Units of Proteolytic Activity (UPA) defined as the amount ( $\mathrm{mEq}$ ) of amino acid tyrosine released as a result of proteolysis of the substrate in the experiment conditions (15).

Lipase (EC 3.1.1.3). The activity of this enzyme was determined in pancreatic homogenate, determining the volume of $0.05 \mathrm{M} \mathrm{NaOH}$ required to neutralize the fatty acids released during $3 \mathrm{hrs}$. of incubation, with gentle stirring, at $37^{\circ} \mathrm{C}$ with $3 \mathrm{ml}$ of olive oil used as substrate. The activity was expressed as $\mu \mathrm{l}$ of $\mathrm{NaOH} / \mathrm{mg}$ protein (16).

Protein Analysis. Protein content was determined by reacting the samples with a filtered solution on 40 Whatman paper containing 1\% Coomassie Brilliant Blue G250 in ethanol, diluted $1: 2$ in $8.9 \%$ orthophosphoric acid (13) using the corresponding buffer as a
Tripsina (EC 3.4.21.4). El homogenizado de páncreas fue incubado durante $15 \mathrm{~min}$ a $41^{\circ} \mathrm{C}$ con $200 \mu \mathrm{l}$ del sustrato caseína al $1 \%(\mathrm{p} / \mathrm{v})$ en fosfato de sodio $0.1 \mathrm{M}$ a $\mathrm{pH}$ 7.4. La reacción se detuvo con la adición de $1 \mathrm{ml}$ de ácido tricloroacético al $5 \%(\mathrm{p} / \mathrm{v})$ y la mezcla filtrada en papel Whatman 42. Se hicieron reaccionar $250 \mu \mathrm{l}$ del filtrado con $1250 \mu \mathrm{l} \mathrm{de} \mathrm{Na}_{2} \mathrm{CO}_{3} 0.2 \mathrm{M}$ y $250 \mu \mathrm{l}$ del reactivo de Folin-Ciocalteu diluido 1:5 en agua destilada (16). Después de una incubación durante $20 \mathrm{~min}$ a $41^{\circ} \mathrm{C}$ se midió la absorbancia a una longitud de onda de $625 \mathrm{~nm}$. La actividad se expresó como Unidades de Actividad Proteolítica (UAP) definidas como la cantidad ( $\mathrm{mEq}$ ) del aminoácido tirosina liberado como producto de la proteólisis del sustrato en las condiciones del ensayo (15).

Lipasa (EC 3.1.1.3). La actividad de esta enzima se determinó en homogenizado de páncreas, determinando el volumen de $\mathrm{NaOH}$ $0.05 \mathrm{M}$ requerido para neutralizar los ácidos grasos liberados durante $3 \mathrm{~h}$ de incubación, con agitación moderada, a $37^{\circ} \mathrm{C}$ con $3 \mathrm{ml}$ de aceite de oliva utilizado como sustrato. La actividad se expresó como $\mu \mathrm{l}$ de $\mathrm{NaOH} / \mathrm{mg}$ de proteína (16).

Análisis de proteína. El contenido de proteína se determinó haciendo reaccionar las muestras con una solución filtrada en papel Whatman 40 conteniendo azul comassie brillante-G250 al 1\% en etanol, diluida $1: 2$ en ácido ortofosfórico al 8.9\% (13) utilizando el tampón correspondiente como blanco y Albúmina Sérica Bovina (BSA) como estándar.

Análisis estadístico. Los resultados fueron expresados como el promedio \pm la desviación estándar, y analizados estadísticamente a través del Análisis de Kruskal-Wallis y la prueba de rangos promedios a un nivel de significancia $p \leq 0.05$ (17).

\section{RESULTADOS}

Maltasa (EC 3.2.1.20). Inmediatamente después de la eclosión, la actividad específica de la enzima maltasa, determinada en homogenizado de segmentos duodenales, fue de $39 \pm 1$ nmoles de glucosa/min $/ \mathrm{mg}$ de proteína. Tanto a las 48 como a las $72 \mathrm{~h}$ de nacidos, la actividad fue mayor $(p \leq 0.05)$ en los animales que recibieron SHC desde el nacimiento hasta las $48 \mathrm{~h}$ post-eclosión (T2) en comparación con el control, que se mantuvo en ayuno durante $48 \mathrm{~h}$ (Figura 1). Las aves que recibieron $\mathrm{ABH}$ presentaron mayor actividad de esta enzima a las $48 \mathrm{~h}$ de nacidos $(\mathrm{p} \leq 0.05)$.

Sacarasa (EC 3.2.1.48). En el momento de la eclosión, la actividad específica de la enzima sacarasa, determinada en homogenizado de segmentos duodenales, fue de $1.2 \pm 0.1$ nmoles 
blank and Bovine Serum Albumin (BSA) as a standard.

Statistical analysis. The results were expressed as the mean \pm standard deviation and statistically analyzed through a KruskalWallis analysis and the average range tests at a significant level of $p \leq 0.05$ (17).

\section{RESULTS}

Maltase (EC 3.2.1.20). Immediately after hatching, the specific activity of maltase enzyme determined in homogenate of duodenal segments was $39 \pm 1$ nmoles of glucose/min/mg protein. At both 48 and 72 hours old, the activity was higher $(p \leq 0.05)$ in animals receiving CHS from birth until 48 hrs. post-hatching (T2) in comparison with the control, which was kept in fasting for $48 \mathrm{hrs}$. (Figure 1 ). Birds receiving HBF showed higher activity of this enzyme at $48 \mathrm{hrs}$. old $(p \leq 0.05)$.

Sucrase (EC 3.2.1.48). Upon hatching, the specific activity of sucrase, determined in the homogenate of duodenal segments was $1.2 \pm 0.1$ nmoles glucose $/ \mathrm{min} / \mathrm{mg}$ protein, about 32 times lower than the maltase activity after hatching. In the first 48 hrs. after hatching there were no significant differences between treatments. However, at 72 hrs. there were significant differences in favor of T1 and T2 (Figure 1). Therefore, supplying HBF and $\mathrm{CHS}$ in the first $48 \mathrm{hrs}$. of life improved sucrase activity in birds that were 72 hrs. old $(p \leq 0.05)$, leading to increased activity about 3-fold compared to the control.

Alkaline phosphatase (EC 3.1.3.1). Immediately after hatching, the specific activity of the alkaline phosphatase enzyme, determined in homogenate of duodenal segments was $53 \pm 12(\mathrm{U} / \mathrm{L}) / \mathrm{min} / \mathrm{mg}$ protein. At $48 \mathrm{hrs}$. of life, animals that consumed CHS (T2) had 1.2 times higher activity, with significant differences $(p<0.05)$ compared to the control group (T0) (Figure 1). However, in birds that fasted for $48 \mathrm{hrs}$. after hatching (TO) activity significantly increased $(p \leq 0.05)$ on the third day, $24 \mathrm{hrs}$. after receiving food.

Phytase (EC 3.1.3.8). Immediately after hatching, the specific activity of the phytase enzyme, determined in homogenate of duodenal segments was $5.1 \pm 0.2$ nmoles of $\mathrm{PO}_{4} / \mathrm{min} /$ $\mathrm{mg}$ protein. The trend, as in the case of alkaline phosphatase, is increasing in the first 72 hours post-hatching. Early feeding of both $\mathrm{CHS}$ and HBF promoted greater phytase activity in the first 72 hours of life $(p \leq 0.05)$, with increases of up to 3.2 fold compared to the control (Figure 1). de glucosa/min/mg de proteína, cerca de 32 veces más baja que la actividad de la maltasa después de la eclosión. En las primeras $48 \mathrm{~h}$ después de la eclosión no se encontraron diferencias significativas entre los tratamientos. No obstante, a las $72 \mathrm{~h}$ se presentaron diferencias significativas a favor de T1 y T2 (Figura 1). Por tanto, el suministro de $\mathrm{ABH}$ y $\mathrm{SHC}$ en las primeras $48 \mathrm{~h}$ de vida mejoró la actividad de la sacarasa a las $72 \mathrm{~h}$ de edad de las aves $(p \leq 0.05)$, provocando un incremento de la actividad de cerca de 3 veces en comparación con el control.

Fosfatasa Alcalina (EC 3.1.3.1). Inmediatamente después de la eclosión, la actividad específica de la enzima fosfatasa alcalina, determinada en homogenado de segmentos duodenales, fue de $53 \pm 12(\mathrm{U} / \mathrm{L}) / \mathrm{min} / \mathrm{mg}$ de proteína. A las $48 \mathrm{~h}$ de vida, los animales que consumieron el SHC (T2) presentaron una actividad 1.2 veces más alta, con diferencias significativas $(p<0.05)$ en comparación con el grupo control (T0) (Figura 1). No obstante, en las aves mantenidas en ayuno durante 48 h después de la eclosión (TO) se presentó una actividad significativamente mayor $(p \leq 0.05)$ en el tercer día de edad, $24 \mathrm{~h}$ después de recibir el alimento.

Fitasa (EC 3.1.3.8). Inmediatamente después de la eclosión, la actividad específica de la enzima fitasa, determinada en homogenado de segmentos duodenales, fue de $5.1 \pm 0.2 \mathrm{nmoles}$ de $\mathrm{PO}_{4} / \mathrm{min} /$ $\mathrm{mg}$ de proteína. La tendencia, al igual que en el caso de la fosfatasa alcalina, es a aumentar en las primeras $72 \mathrm{~h}$ post-eclosión. El suministro de alimentación temprana, tanto del $\mathrm{ABH}$ como del SHC promovió una mayor actividad fitásica en las primeras $72 \mathrm{~h}$ de nacidos $(p \leq 0.05)$, con incrementos de hasta 3.2 veces en comparación con el control (Figura 1).

En términos generales, en los animales del grupo control que se mantuvieron en ayuno durante $48 \mathrm{~h}$, se evidenció, como efecto de suministrar alimentación después del período de ayuno, un aumento en la actividad de las enzimas integrales del borde en cepillo intestinal, en este caso en el segmento duodenal, maltasa, sacarasa, fosfatasa alcalina y fitasa, a las $72 \mathrm{~h}$ después de la eclosión. Asimismo, en las aves que recibieron algún tipo de alimento o suplemento ( $\mathrm{ABH}$ ○ $\mathrm{SHC}$ ) durante las primeras $48 \mathrm{~h}$ de edad, se observó una marcada tendencia al incremento de la actividad de estas enzimas digestivas.

$\alpha$-Amilasa (EC 3.2.1.1). Inmediatamente después de la eclosión, la actividad específica de la enzima $\alpha$-amilasa, determinada en homogenizado de páncreas, fue de $94 \pm 7 \mu \mathrm{g}$ de almidón degradado/ $\mathrm{min} / \mathrm{mg}$ de proteína. La tendencia fue a presentarse un valor mayor en las $48 \mathrm{~h}$ y a disminuir a las $72 \mathrm{~h}$. 
Overall, in animals in the control group that fasted for $48 \mathrm{hrs}$. there was an effect of providing food after the fasting period, which caused an increase in the activity of integral enzymes in the intestinal brush border. In this case, in the duodenal segment, maltase, sucrase, alkaline phosphatase and phytase, at 72 hrs. after hatching. Similarly, in birds given some food or supplement (HBF or CHS) during the first 48 hrs. of life, a marked increasing tendency in the activity of these digestive enzymes was observed.

$\alpha$-Amylase (EC 3.2.1.1). Immediately after hatching, the specific activity of the $\alpha$-amylase enzyme, determined in pancreatic homogenate, was $94 \pm 7 \mu \mathrm{g}$ of degraded starch $\mathrm{min} / \mathrm{mg}$ protein. The trend was to present a greater value at $48 \mathrm{hrs}$. and to diminish at $72 \mathrm{hrs}$.

At 48 hrs. old, chickens receiving all treatments showed significantly lower activity of this enzyme $(p \leq 0.05)$ in comparison with control animals, with greater activity in T0 very close to $300 \%$ with respect to immediately lesser treatment [T2] (Figure 2).
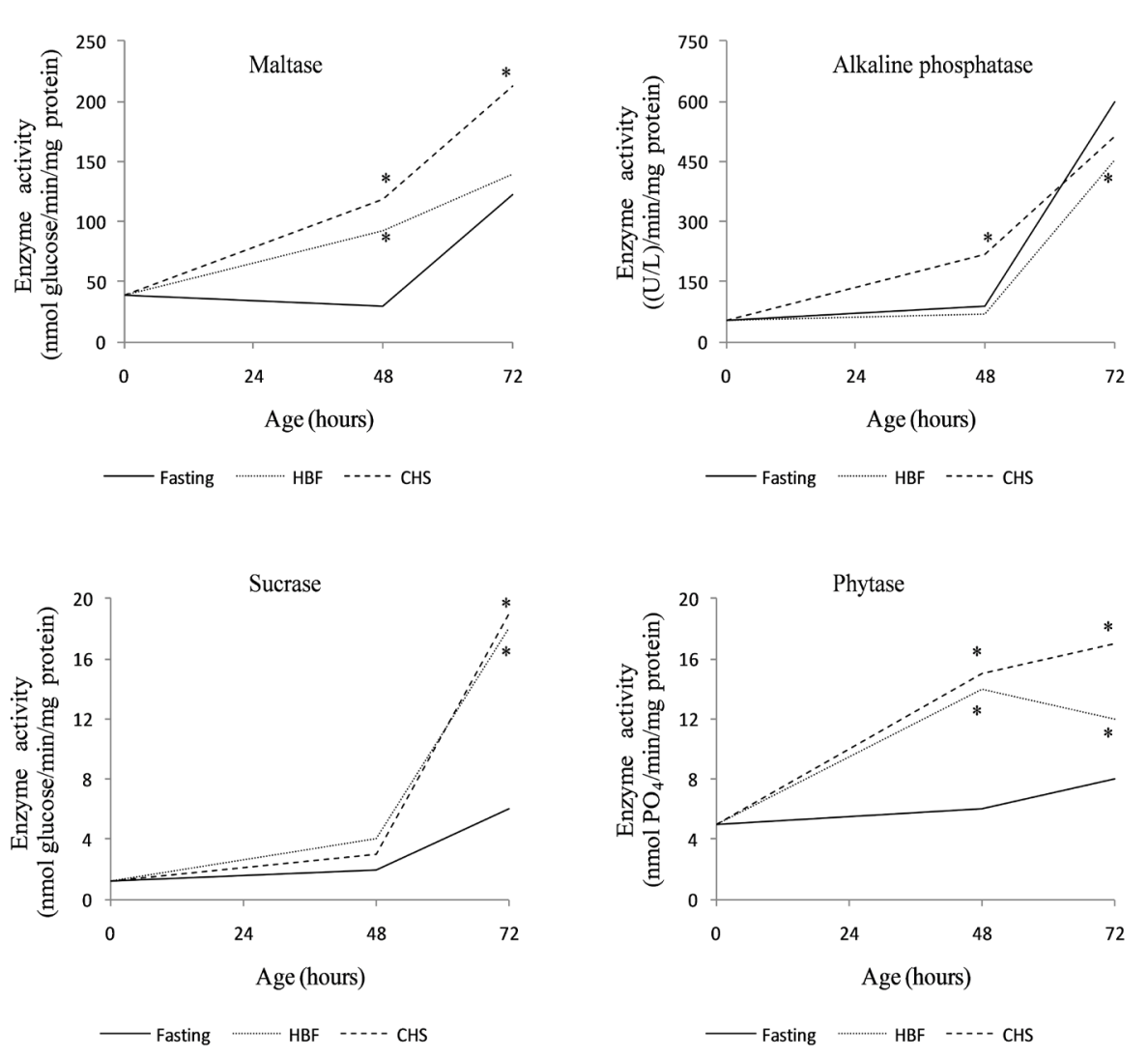

Figure 1. Specific activity of duodenal digestive enzymes in broiler chickens in fasting or early feeding.

Fasting from hatching to 48 hrs. HBF = hydrated balanced feed supplied from hatching to 48 hrs. $\mathrm{CHS}=$ commercial hydrating supplement supplied from hatching to $48 \mathrm{hrs} *(p<0.05)$.
A las $48 \mathrm{~h}$ de edad los pollos de todos los tratamientos presentaron una actividad de esta enzima significativamente menor $(p \leq 0.05)$ en comparación con los animales del grupo control, siendo mayor la actividad en T0 muy cercana al $300 \%$ con respecto al tratamiento inmediatamente inferior [T2], (Figura 2).

Tripsina (EC 3.4.21.4). Inmediatamente después de la eclosión, la actividad específica de la enzima tripsina, determinada en homogenizado de páncreas, fue de $0.3 \pm 0.06 \mathrm{UAP} / \mathrm{min} / \mathrm{mg}$ de proteína y mostró una tendencia, en los animales del grupo control, al incremento en las primeras $72 \mathrm{~h}$ de vida.

El suministro de $\mathrm{ABH}$ o $\mathrm{SHC}$ no aumentó la actividad de esta enzima (Figura 2). En las primeras $48 \mathrm{~h}$ de edad, la actividad fue semejante tanto en los animales en ayuno como en aquellos que recibieron algún tipo de alimento o suplemento. A partir de las $48 \mathrm{~h}$ de edad, se observa un marcado incremento en la actividad de la tripsina únicamente en los animales que se habían mantenido en condiciones de ayuno (T0) y una disminución significativa $(p \leq 0.05)$ en 

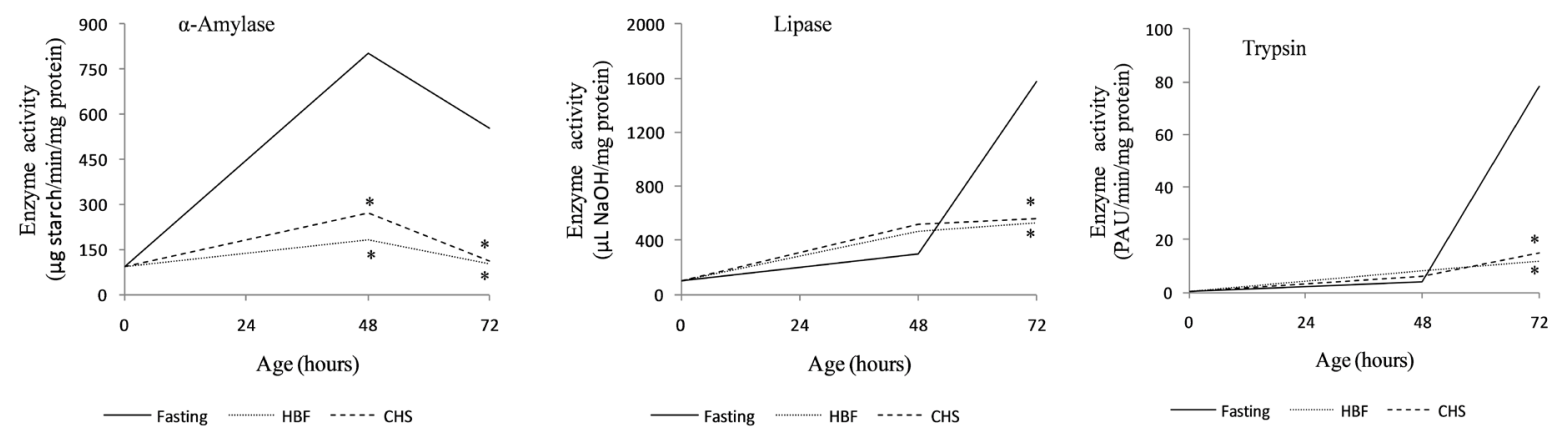

Figure 2. Specific activity of pancreatic digestive enzymes in broiler chickens in fasting or early feeding. Fasting from hatching to $48 \mathrm{hrs}$. HBF = hydrated balanced feed supplied from hatching to 48 hrs. $\mathrm{CHS}=$ commercial hydrating supplement supplied from hatching to 48 hrs. * $(p \leq 0.05)$.

Trypsin (EC 3.4.21.4). Immediately after hatching, the specific activity of the trypsin enzyme, determined in pancreatic homogenate, was $0.3 \pm 0.06 \mathrm{PAU} / \mathrm{min} / \mathrm{mg}$ protein and showed an increasing trend in the control animals, in the first 72 hrs. of life.

Supplying CHS or HBF did not increase the activity of this enzyme (Figure 2). In the first 48 hrs. of life, activity was similar in both animals that fasted and those that received any food or supplements. After 48 hours of age, a marked increase in trypsin activity was observed only in animals that had been fasting (TO) and a significant reduction $(p \leq 0.05)$ in activity is observed in groups that received $\mathrm{HBF}$ and $\mathrm{CHS}$ ( $\mathrm{T} 1$ and $\mathrm{T} 2$ ).

Lipase (EC 3.1.1.3). Immediately after hatching, the specific activity of the lipase enzyme, determined in pancreatic homogenate, was $106 \pm 17 \mu \mathrm{l}$ of $\mathrm{NaOH} / \mathrm{mg}$ protein. The general trend was increasing in the first 72 hrs.

On the second day of life, all treatments showed a tendency to increase this enzyme's activity in relation to birth, even in birds that were under total fasting conditions (TO). At 72 hrs. accelerated activity of this enzyme was observed in the group of animals that fasted for $48 \mathrm{hrs}$. (Figure 2).

\section{DISCUSSION}

The supply of both HBF and CHS provided from birth until 48 hrs. post-hatching caused an increase in the activity of the maltase enzyme. This effect could have a favorable impact, in terms of better digestive activity, increased glucose uptake from the diet, and at the same la actividad en los grupos que recibieron $\mathrm{ABH}$ y SHC (T1 y T2).

Lipasa (EC 3.1.1.3). Inmediatamente después de la eclosión, la actividad específica de la enzima lipasa, determinada en homogenizado de páncreas, fue de $106 \pm 17 \mu \mathrm{l}$ de $\mathrm{NaOH} /$ $\mathrm{mg}$ de proteína. La tendencia general fue a incrementarse en las primeras $72 \mathrm{~h}$.

Al segundo día de edad, todos los tratamientos presentaron una tendencia al incremento en la actividad de esta enzima, con relación a la actividad al nacimiento, aún en las aves que estuvieron bajo ayuno total (T0). A las 72 h, se observó un incremento acelerado en la actividad de esta enzima en el grupo de animales que estuvo bajo ayuno durante $48 \mathrm{~h}$ (Figura 2 ).

\section{DISCUSIÓN}

Tanto el suministro de $\mathrm{ABH}$ como el SHC suministrados desde el nacimiento hasta las $48 \mathrm{~h}$ post-eclosión provocaron un aumento en la actividad de la enzima maltasa. Este efecto pudiese repercutir favorablemente en una mejor actividad digestiva y mayor absorción de glucosa proveniente de la dieta, lo que al mismo tiempo permitiría mejorar el metabolismo energético del ave. La actividad específica de la maltasa presentó una tendencia marcada al incremento con la edad, en concordancia con lo reportado por otros autores (13).

La actividad de la sacarasa fue casi 32 veces más baja que la actividad de la maltasa después de la eclosión. En pollos de mayor edad se ha reportado que la actividad de la sacarasa suele ser alrededor de 13 a $16 \%$ menor que la de la maltasa (13). El suministro de ABH y SHC en las 
time would improve the energy metabolism of the bird. The specific activity of maltase showed a marked increase with age, in agreement with trends reported by other authors (13).

Sucrase activity was almost 32 times lower than maltase activity after hatching. In older chickens, it has been reported that sucrase activity is usually about 13 to $16 \%$ lower than that of maltase (13). Providing HBF and CHS in the first $48 \mathrm{hrs}$. of life increased sucrase activity at $72 \mathrm{hrs}$. $(p \leq 0.05)$. Like maltase, specific sucrase activity increased with the age of the animals over the time span of the study period and increased after food restriction; similar to findings reported by Pinheiro et al (18). It has been reported that digestive enzyme activity may be affected by characteristics of diet and availability of substrate (19), among other factors. The activity of the enzymes maltase, sucrase, alkaline phosphatase and phytase, all integral catalytic proteins of the intestinal brush border, determined in the duodenal segment, increased in the first $72 \mathrm{hrs}$. of life in groups that received some type of food or supplement immediately after hatching.

In assessing the effect of feed restriction between 7 and 14 days of life in broiler chickens, an increase was reported in maltase and sucrase activity immediately after the restriction period (18). This could be applied to partially explain the effect of the food supply at $48 \mathrm{hrs}$. on birds in the control group, by increasing the activity of duodenal enzymes.

As for pancreatic enzymes, some authors have reported that specific activity of digestive enzymes increases with age, peaking in the pancreas on the 8th day for amylase and lipase, on the 11th day for trypsin and on the $17^{\text {th }}$ day for amylase (9). During the first 48 hrs. of life, trypsin activity was similar in all groups, including animals that were fasting, indicating that activity is not very dependent on the presence of substrate, in accordance with findings reported by other authors (20) who observed that trypsin activity was not affected after evaluating two different energy levels in the diet of broiler chickens during the first week of life. The results obtained in the present study may be related to previous studies which have shown that when you start feeding chickens $36 \mathrm{hrs}$. after hatching there is a significant decrease in body weight in the first three days of life (11) as well as growth retardation and reduced meat production (6), which may result from decreased digestive enzyme activity in the intestinal brush border.

In conclusion, providing $\mathrm{HBF}$ or $\mathrm{CHS}$ to chickens during the first 48 hours of life increased specific primeras $48 \mathrm{~h}$ de vida aumentó la actividad de la sacarasa a las $72 \mathrm{~h}(\mathrm{p} \leq 0.05)$. Al igual que la maltasa, la actividad específica de la sacarasa se incrementó con la edad de los animales en el lapso de tiempo que duró el estudio y aumentó después del período de restricción de alimentos; de manera similar a lo reportado por Pinheiro et al (18). Se ha reportado que la actividad de las enzimas digestivas puede ser afectada por las características de la dieta y la disponibilidad del sustrato (19), entre otros factores. La actividad de las enzimas maltasa, sacarasa, fosfatasa alcalina y fitasa, todas proteínas catalíticas integrales del borde en cepillo intestinal, determinadas en el segmento duodenal, aumentó en las primeras $72 \mathrm{~h}$ de edad de las aves en los grupos que recibieron algún tipo de alimento o suplemento desde inmediatamente después de la eclosión.

Al evaluar el efecto de la restricción de alimento entre 7 y 14 días de edad, en pollos de engorde, se reportó un aumento en la actividad de las enzimas maltasa y sacarasa inmediatamente después del período de restricción (18). Esto podría aplicarse para explicar en parte el efecto del suministro de alimento a las $48 \mathrm{~h}$ de edad, en las aves del grupo control, al incrementar la actividad de las enzimas duodenales.

En cuanto a las enzimas pancreáticas, algunos autores han reportado que la actividad específica de las enzimas digestivas aumenta con la edad, alcanzando valores máximos en el páncreas al $8^{\text {vo }}$ día para amilasa y lipasa y al $11^{\text {vo }}$ día para tripsina. En el contenido intestinal la actividad máxima se observó al $4^{\text {to }}$ día para lipasa, al $11^{\text {vo }}$ día tripsina y al $17^{\text {vo }}$ día en amilasa (9). Durante las primeras $48 \mathrm{~h}$ de edad, la actividad de la tripsina fue semejante en todos los grupos, incluyendo a los animales en ayuno, indicando una actividad poco dependiente de la presencia del sustrato, en concordancia por lo reportado por otros autores (20) al observar que la actividad de la tripsina no fue afectada después de evaluar dos niveles diferentes de energía en la dieta en pollos de engorde durante la primera semana de vida. Los resultados obtenidos en el presente estudio podrían estar relacionados con estudios previos en los cuales se ha demostrado que al iniciar la alimentación de los pollos 36 h después de la eclosión se produjo disminución significativa del peso vivo en los primeros tres días de edad (11), así como retardo del crecimiento y menor producción de carne (6), lo que puede ser consecuencia de una menor actividad de las enzimas digestivas del borde en cepillo intestinal.

En conclusión el suministro de $\mathrm{ABH}$ o $\mathrm{SHC}$ durante las primeras $48 \mathrm{~h}$ de vida de los pollos aumentó 
activity of duodenal enzymes along the intestinal brush border: maltase, sucrase and phytase, and decreased pancreatic enzyme activity for $\alpha$-amylase, trypsin and lipase in the first 3 days of life.

\section{Acknowledgements}

The Council of Scientific and Humanistic Development of the Central University of Venezuela for funding this research through Project Group No. PG-11-7118-2008/1. la actividad específica de las enzimas duodenales del borde en cepillo intestinal maltasa, sacarasa y fitasa y disminuyó la actividad de las enzimas pancreáticas $\alpha$-amilasa, tripsina y lipasa en los primeros 3 días de edad.

\section{Agradecimientos}

Al Consejo de Desarrollo Científico y Humanístico de la Universidad Central de Venezuela por el financiamiento de la presente investigación, a través del Proyecto de Grupo No PG-11-71182008/1.

\section{REFERENCES}

1. López C, Menocal J, González, E. Mitos y realidades del sistema digestivo y sus implicaciones sobre la productividad. Asociación española de ciencia avícolaWPSA. 2005. (Fecha de acceso 15 de octubre de 2012). URL disponible en http://www.wpsaaeca.es/articulo.php?id_ articulo $=236$.

2. Careghi C, Tona K, Onagbesan O, Buyse J, Decuypere E, Bruggeman V. The effects of the spread of hatch and interaction with delayed feed access after hatch on broiler performance until seven days of age. Poult Sci 2005; 84(8):1314-1320.

3. Suzuki T, Noguchi J, Kitamura M, Fujisaki H. Effects of newly developed early posthatch feed for poultry hatchlings on the performance of poultry. J Poult Sci 2008; 45(1):39-45.

4. Kidd MT, Taylor JW, Page CM, Lott BD, Chamblee TN. Hatchery feeding of starter diets to broiler chicks. J Appl Poult Res 2007; 16:234-239.

5. Mbajiorgu CA, Ng'ambi JW, Norris D. Effect of time of initiation of feeding after hatching and influence of dietary ascorbic acid supplementation on productivity, mortality and carcass characteristics of Ross 308 broiler chickens in South Africa. Internat J Poult Sci 2007; 6(8):583-591.

6. El-Husseiny OM, El-Wafa SA, El-Komy HMA. Influence of fasting or early feeding on broiler performance. Internat ] Poult Sci 2008; 7(3):263-271.
7. Cuervo M, Gómez C, Romero H. Efecto de la utilización de un suplemento nutricional hidratado en pollos de engorde recién nacidos. Rev Colom Cienc Pecua 2002; 15(3):319-329.

8. Van den Brand $H$, Molenaar $R$, van der Star I, Meijerhof R. 2010. Early feeding affects resistance against cold exposure in young broiler chickens. Poult Sci 2010; 89(4):716720.

9. Maiorka A, Dahlke F, Azevedo MS. Broiler adaptation to post-hatching period. Cienc Rural 2006; 36(2):701-708.

10. Richards MP, Proszkowiec-Weglarz M, Rosebrough RW, McMurtry JP, Angel R. Effects of early neonatal development and delayed feeding immediately post-hatch on the hepatic lipogenic program in broiler chicks.Comp Biochem Physiol B Biochem Mol Biol 2010; 157(4):374-388.

11. Mbajiorgu CA, Ng'ambi JW, Norris DD. Voluntary feed intake and nutrient composition in chickens. Asian J Anim Vet Adv 2011; 6:20-28.

12. Association of Official Analytical Chemist. Official Methods of Analysis $19^{\text {th }}$ ed. Arlington, VA; 2012.

13. Rueda $E$, León $M$, Castañeda $M$, Mendez $A$, Michelangeli $C$. Effects of Concanavalin A on intestinal brush border enzyme activity in broiler chickens. Br Poult Sci 2007; 48(6):696-702. 
14. Pizzani P, Godoy S, León M, Rueda E, Castañeda MV, Arias A. Efecto de concentraciones crecientes de fósforo fítico sobre la actividad de las enzimas fitasa y fosfatasa alcalina en el epitelio intestinal de ovinos jóvenes. Rev Cient-Fac Cien V 2008; 18(1):59-64.

15. León $M$, Rueda $E$, Castañeda $M$, Mendez $A$, Michelangeli $C$. Efecto de la concanavalina a sobre la actividad de las enzimas $\alpha$-amilasa y tripsina en pollos de engorde. Rev CientFac Cien V 2007; 17(1):83-88.

16. Beisson F, Tiss A, Riviere C, Verger R. Methods for lipase detection and assay: a critical review. Eur J Lipid Sci Technol 2000; 102(2):133-153.
17. Statistix [programa de ordenador] version 9. USA: Analytical software; 2008.

18. Pinheiro $D$, Cruz V, Sartori J, Vicentini M. Effect of early feed restriction and enzyme supplementation on digestive enzyme activities in broilers. Poult Sci 2004; 83(9):1544-1550.

19. Uni Z, Ferket R. Methods for early nutrition and their potential. World's Poult Sci J 2004; 60(1):101-111.

20. Maiorka A, Fischer da Silva AV, Santin E, Pizauro JM, Macari M. Broiler breeder age and dietary energy level on performance and pancreas lipase and trypsin activities of 7-days old chicks. Internat J Poult Sci 2004; 3(3):234-237. 